\title{
Radiological Pitfalls of a Large Intracranial Dissecting Aneurysm
}

\section{Büyük Intrakraniyal Disekan Anerrizmada Radyolojik Zorluklar}

\author{
Rabih ABOUKAIS, Fahed ZAIRI, Philippe BOURGEOIS, Laurent THINES, Jean-Paul LEJEUNE
}

Lille University Hospital, Department of Neurosurgery, Lille, France

Corresponding Author: Rabih ABOUKAIS / E-mail: rabihdoc@hotmail.com

\begin{abstract}
We report the case of a large dissecting aneurysm of the anterior cerebral artery revealed by cerebral infarction in 38-year-old man. The volume and aspect of the aneurysm initially led us to the diagnosis of saccular aneurysm. Given the complete thrombosis, the risk of bleeding was low and antithrombotic therapy was started. Surgery could be discussed later. However radiological monitoring by MRI (magnetic resonance imaging) showed a rapid decrease in volume of the aneurysm. The final angiography found an aspect of stenosis followed by a little arterial dilatation. The diagnosis of dissecting anterior cerebral aneurysm was a posteriori established.
\end{abstract}

KEYWORDS: Dissecting aneurysm, Ischemic stroke, Haemorrhage, Angiography

\section{öz}

38 yaşında bir erkekte serebral infarktüsle ortaya çıkan anterior serebral arterin büyük disekan anevrizması olgusunu bildiriyoruz. Anevrizmanın büyüklüğü ve yeri başlangıçta sakküler anevrizma tanısı düşündürdü. Tam tromboz olduğu dikkate alındığında kanama riski düşüktü ve antitrombotik tedavi başlandı. Cerrahi seçeneği daha sonra değerlendirilecekti. Ancak manyetik rezonans görüntüleme (MRG) ile radyolojik izleme anevrizmanın hacminde hızlı bir azalma gösterdi. Son anjiyografi bir miktar stenoz ve sonrasında biraz arteriyel dilatasyon buldu. Sonradan disekan anterior serebral anevrizma tanısı kondu.

ANAHTAR SÖZCÜKLER: Disekan anevrizma, İskemik inme, Kanama, Anjiyografi

\section{INTRODUCTION}

Intracranial dissecting aneurysms have been increasingly reported and are recognized as a common cause of stroke (9). Spontaneous dissecting aneurysms occur most commonly in the vertebrobasilar circulation and are frequently revealed by subarachnoid haemorrhage (13). Radiological diagnosis is difficult as the typical double lumen aspect is rarely found. This diagnosis should therefore be systematically discussed, especially in young patients (9). The treatment remains controversial.

We report a rare case of large dissecting aneurysm revealed by an ischemic stroke that was initially misdiagnosed due to the atypical clinical and radiological presentation.

\section{CASE REPORT}

A 38-year-old male, without any medical history, was admitted to our institution for progressive headaches of 8 days duration. Physical examination revealed a weakness of the left lower limb. Brain CT scan showed a rounded hyperdense lesion in the interhemispheric fissure. Magnetic resonance imaging (MRI) confirmed a large thrombosed aneurysm of the right anterior cerebral artery (ACA) located at the CA1-CA2 junction. It also revealed a recent ischemic stroke in the right ACA territory (Figure $1 \mathrm{~A}-\mathrm{C}$ ). The aneurismal sac measured
$20 \mathrm{~mm}$ and its orientation was left-sided. Conventional angiography confirmed complete aneurysm thrombosis by the absence of blood circulation in the aneurismal sac. It also detected a small saccular aneurysm of the left middle cerebral artery (MCA). We then retained the diagnosis of thrombosed saccular aneurysm complicated by an ischemic stroke. Given the complete thrombosis of the aneurysm, the risk of bleeding was estimated to be low and as the aneurysm was revealed by ischemia, we introduced antiplatelet therapy (Aspirin ${ }^{\oplus} 75 \mathrm{mg}$ a day). Clinical and MRI monitoring for both aneurysms has been decided in the multidisciplinary meeting. The aneurysm of the left MCA was stable over time, while the thrombosed ACA aneurysm progressively decreased in size (Figure $2 A, B$ ). Due to this change, the hypothesis of a dissecting aneurysm was discussed, but as there was no recanalization, we decided to continue the simple supervision. At 3 years, the MRI was in favor of a partial recanalization of the aneurysm. Conventional angiography depicted a typical aspect of dissecting aneurysm, which associates narrowing followed by lumen dilatation (Figure $3 A, B$ ). Supervision is still ongoing.

\section{DISCUSSION}

\section{Clinical Findings}

Intracranial dissecting aneurysms have been increasingly reported and are recognized as a common cause of stroke. 
Spontaneous dissecting aneurysms occur most commonly in the vertebrobasilar circulation and are frequently revealed by subarachnoid haemorrhage. Anterior dissecting aneurysms are rare, occur more likely in internal carotid and middle cerebral arteries (5) and are commonly revealed by ischemic attack. ACA dissecting aneurysms are known to occur in younger patients (13) (mean age 48.2 years) with a slight male predominance (12). Hypertension and atherosclerosis may be risk factors (13). Intracranial artery dissection may be related to connective tissue diseases affecting the arterial wall like fibromuscular dysplasia or autosomal dominant polycystic kidney disease which have been reported to be other possible causes (11). Regardless of the location, haemorrhagic forms occur in patients harbouring significant dilatation or fusiform aneurysm while ischemic forms occur in the presence of a stenosis. In our case the dissection has been revealed by ischemic stroke despite the significant size of the dilatation, as it was completely thrombosed. Headache is the most common symptom and is thought to be caused by the dissection of the arterial wall (6).

\section{Radiological Findings}

Diagnosis of dissecting aneurysm of anterior cerebral artery is difficult at the initial angiographic examination $(5,10)$, as the pathognomonic double lumen aspect is rarely found. The "string signs" and "rosette signs" are sometimes described and help to guide the diagnosis (14). More common and non specific findings are dilatation, narrowing, pooling of contrast medium and occlusion of anterior cerebral artery. Our case harboured only a completely thrombosed saccular dilatation, and that is why dissecting aneurysm has been initially misdiagnosed. Large or giant saccular aneurysms
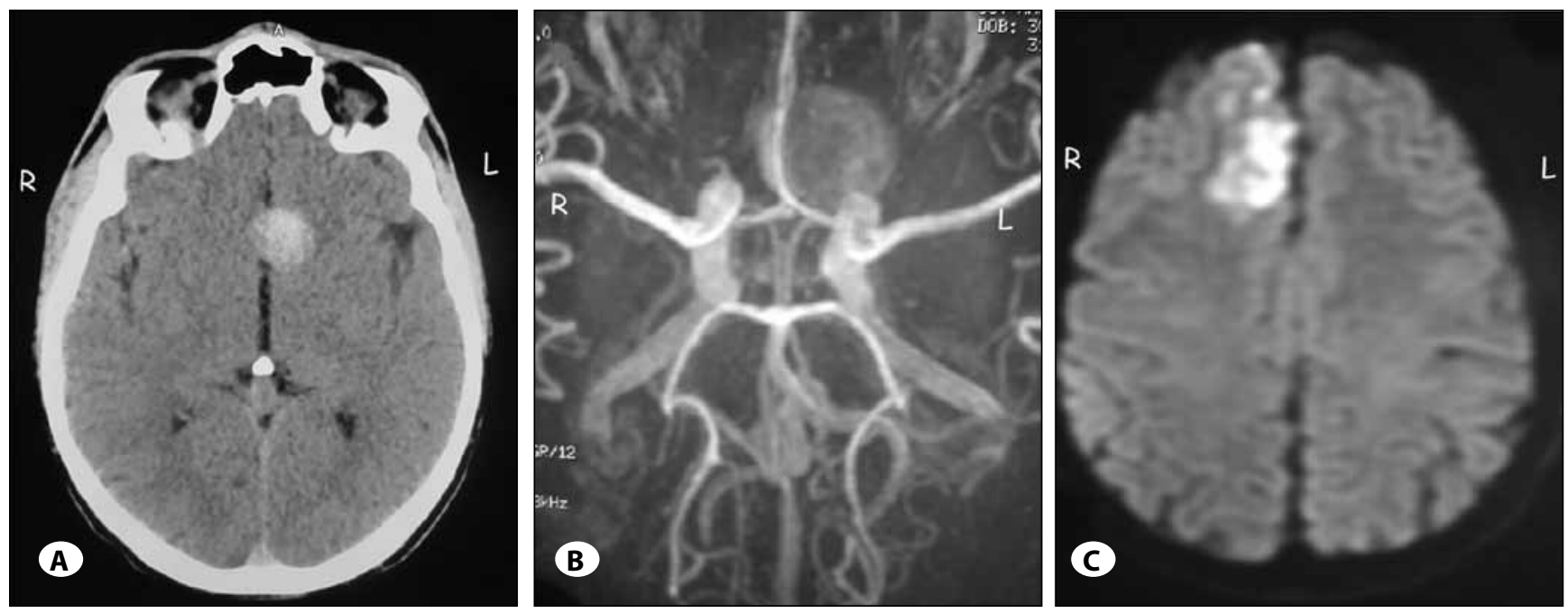

Figure 1: A) Initial brain CT scan and B) angio MRI revealing a large thrombosed aneurysm. C) MRI confirmed an ischemic stroke in the right anterior cerebral artery territory.
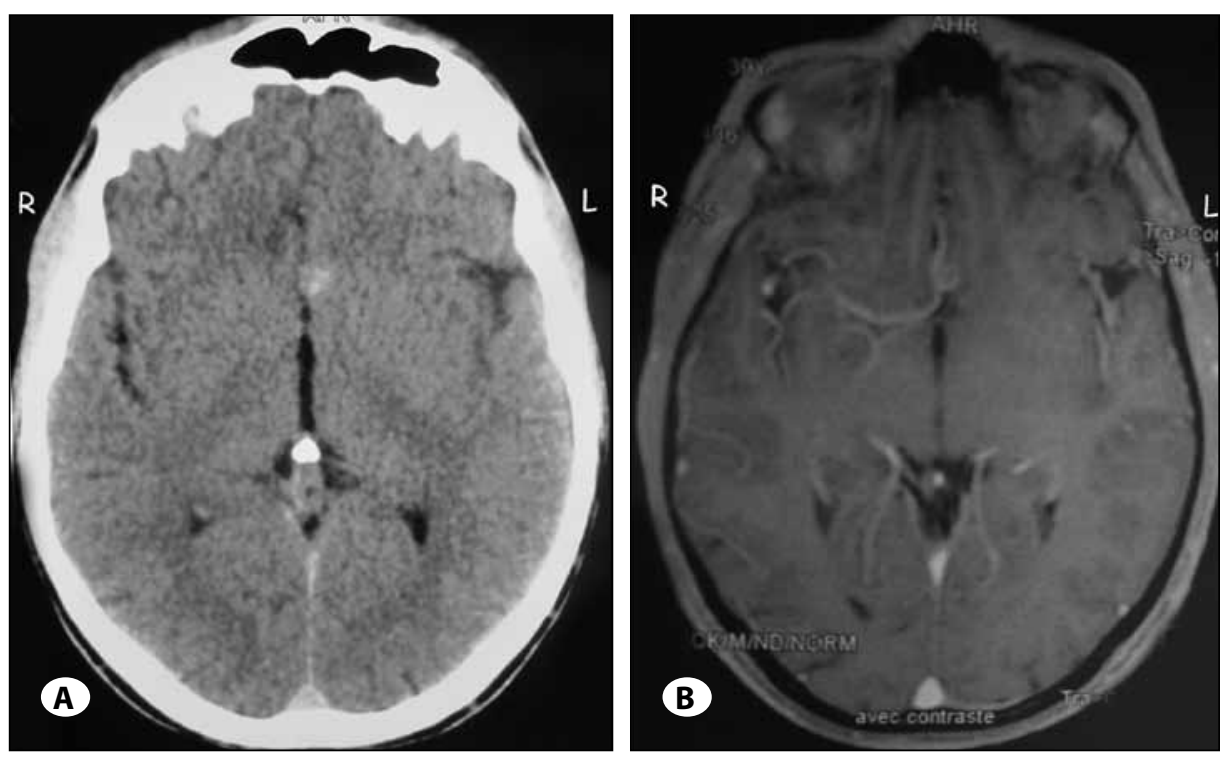

Figure 2: A) Brain CT scan and B) axial weighted T1 MRI at 3 months, which depicted the spontaneous decrease of the aneurysm size. 

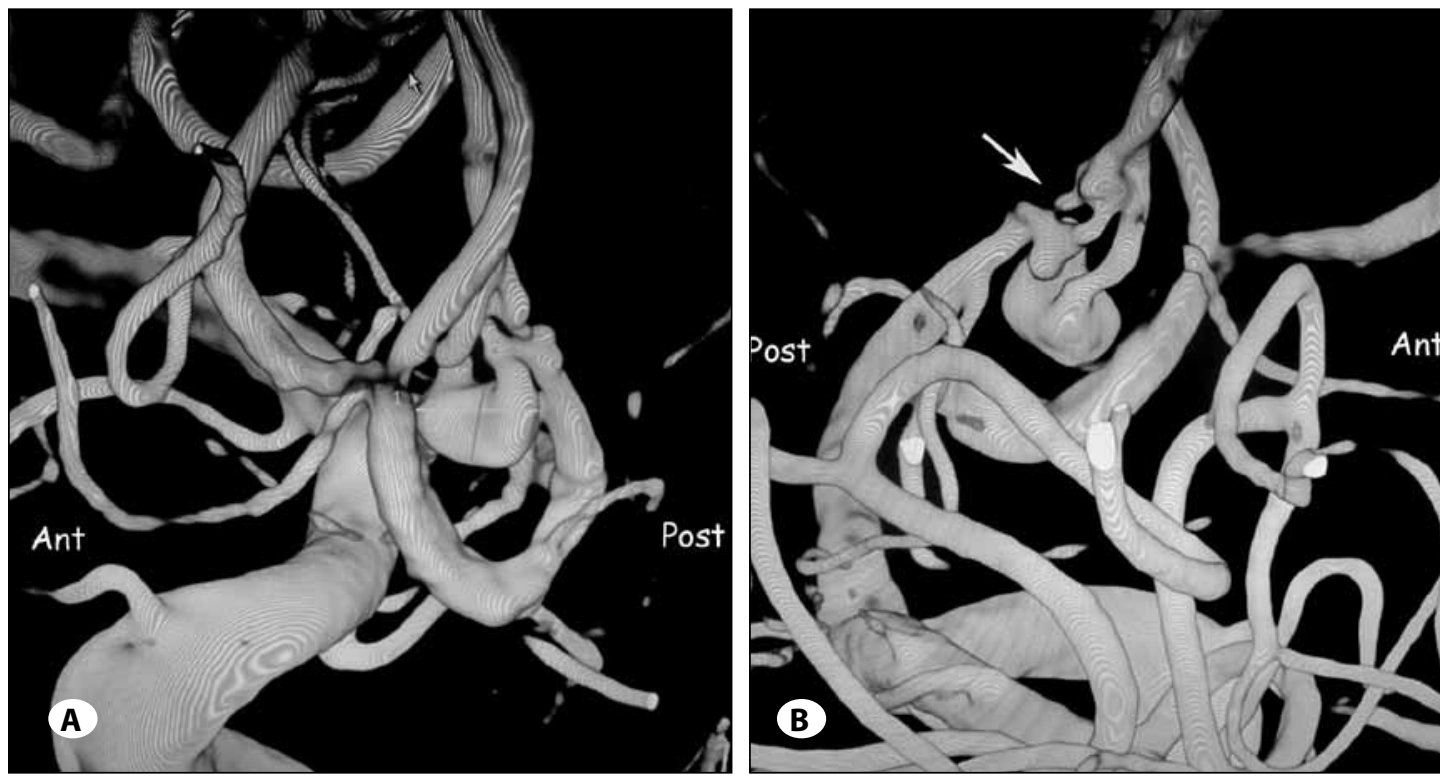

Figure 3: A,B)

3D Conventional angiography at 3 years. It showed a typical aspect of arterial dissection that associates dilatation followed by narrowing (arrow).

are frequently associated with thrombosis, but complete obliteration of the aneurysmal sac is uncommon (2). Moreover, any changing vascular lesions must lead to suspect a dissecting aneurysm. Indeed, some previous reports showed the evolving nature of dissecting aneurysms, which tend to resolve in few months $(4,9)$.

\section{Treatment}

Ideal treatment of dissecting aneurysms in the anterior circulation remains controversial. Dissecting aneurysms revealed by haemorrhage can be effectively treated conservatively with a good outcome and a low rate of rebleeding. Surgical management is recommended if there is a high risk of rebleeding $(11,12)$ (rebleeding under conservative treatment, growing aneurysm, giant aneurysm or uncontrolled hypertension). Many surgical procedures have been proposed such as wrapping, trapping with or without bypass surgery or clipping of the aneurismal bulge (8). For dissecting aneurysm without haemorrhage, conservative treatment must be advocated, as the arterial wall is likely to spontaneously repairs in few weeks (7). In case of ischemic stroke, the use of anti-thrombotic therapy is advised (3). Surgery should only be performed if a haemorrhage occurs during the follow-up (13). In the present case, the close radiological monitoring confirmed that the aneurysm significantly decreased in size. The patient experienced a good outcome and anti-thrombotic therapy was stopped when angiography confirmed healing of the arterial wall.

\section{CONCLUSION}

Dissecting aneurysm must be widely suspected in case of giant aneurysm. Repeated CT scan or MRI can help to guide the diagnosis by revealing dynamic changes in form or in size. Conservative treatment is recommended with good outcome.

\section{REFERENCES}

1. Araki T, Ouchi M, Ikeda Y: A case of anterior cerebral artery dissecting aneurysm. No Shinkei Geka 24:87-91, 1996

2. Artmann $\mathrm{H}$, Vonofakos $\mathrm{D}$, Muller $\mathrm{H}$, Grau $\mathrm{H}$ : Neuroradiologic and neuropathologic findings with growing giant intracranial aneurysm. Review of the literature. Surg Neurol 21:391-401, 1984

3. Chaves C, Estol C, Esnaola MM, Gorson K, O'Donoghue M, De Witt LD, Caplan LR: Spontaneous intracranial internal carotid artery dissection: Report of 10 patients. Arch Neurol 59: 977-981, 2002

4. Ishikawa R, Sunagawa S, Itoh I, Iwashita K: An experience of dissecting cerebral aneurysm of the anterior cerebral artery. No Shinkei Geka 21:355-359, 1993

5. Koyama S, Kotani A, Sasaki J: Spontaneous dissecting aneurysm of the anterior cerebral artery: Report of two cases. Surg Neurol 46:55-61, 1996

6. Kurino M, Yoshioka S, Ushio Y: Spontaneous dissecting aneurysms of anterior and middle cerebral artery associated with brain infarction: A case report and review of the literature. Surg Neurol 57:428-436, 2002

7. Mizutani T, Kojima H, Asamoto S, Miki Y: Pathological mechanism and three-dimensional structure of cerebral dissecting aneurysms. J Neurosurg 94:712-717, 2001

8. Nagata N, Sato K: Surgical treatment for the dissecting aneurysm of the anterior cerebral artery. Surg Cereb Stroke (Jpn) 24:80-84, 1996

9. Ohkuma H, Suzuki S, Kikkawa T, Shimamura N: Neauroradiologic and clinical features of arterial dissection of the anterior cerebral artery. AJNR Am J Neuroradiol 24:691-699, 2003

10. Otawara Y, Suzuki M, Abe M, Tomizuka N, Ogawa A: Dissecting aneurysms of the anterior cerebral artery and accessory middle cerebral artery: Case report. Neurosurg Rev 20: 145-148, 1997 
11. Thines L, Zairi F, Taschner C, Leclerc $X$, Lucas $C$, Bourgeois $P$, Lejeune JP: Subarachnoid hemorrhage from spontaneous dissection of the anterior cerebral artery. Cerebrovasc Dis 22:452-456, 2006

12. Wakabayashi $\mathrm{Y}$, Nakano $\mathrm{T}$, Isono $\mathrm{M}$, Shimomura T, Hori S: Dissecting aneurysm of the anterior cerebral artery requiring surgical treatment. Case report. Neurol Med Chir (Tokyo) 40:624-627, 2000
13. Yamaura A, Yoshimoto T, Hashimoto N, Ono J: Nationwide study of nontraumatic intracranial arterial dissection clinical features and outcome. Surg Cereb Stroke (Jpn) 26:79-86, 1998

14. Yonas H, Agamanolis D, Takaoka Y, White RJ: Dissecting intracranial aneurysms. Surg Neurol 8:407-415, 1977 